\title{
Meningkatkan Minat Dan Kemampuan Siswa Dalam Menulis Karangan (Teks Eksemplum) Melalui Media Gambar Pada Siswa Kelas VII.A Semester 1 SMP Negeri 2 Pujut Kabupaten Lombok Tengah Tahun Pelajaran 2019/2020
}

\author{
Zaenudin \\ Guru Mata Pelajaran Bahasa Indonesia SMP Negeri 2 Pujut Kabupaten Lombok Tengah
}

\begin{abstract}
Abstrak. Salah satu peran guru yang sangat penting adalah menciptakan proses pembelajaran yang bermutu, berkualitas dan menyenangkan. Adapun tujuan dari penelitian tindakan kelas ini untuk mengetahui seberapa besar dampak peningkatan minat siswa terhadap penggunaan media gambar yang diinterprestasikan menjadi sebuah karangan Meningkatkan kemampuan minat siswa dapat dilihat dari beberapa aspek yaitu : aktivitas siswa, aktivitas guru dan efektivitas proses pembelajaran, dan nilai hasil prestasi siswa . Teknik yang digunakan adalah dengan pendekatan penelitian tindakan kelas, teknik pengumpulan data observasi, dan tes hasil belajar siswa. Perolehan data baik aktivitas siswa maupun nilai hasil belajar sisiwa pada siklus I dan II dalam penelitian tindakan kelas dapat ditafsirkan sebagai berikut ; (1) Minat dan kemampuan siswa terhadap pembelajaran menulis karangan sangat baik. (2) Media Gambar sangat membantu siswa dalam meningkatkan imajinasi sehingga mampu membuat kalimat sederhana yang menjadi kerangka karangan dan kemudian dikembangkan lagi. (3) Siswa mampu menginterprestasikan kalimat sederhana dengan cara mengkaitkan gambar seri yang diamatinya. (4) Siswa mampu mengkomunikasikan tulisannya berdasarkan hasil pengamatan kepada temannya maupun kepada guru. (5) Proses pembelajaran lebih variatif sehingga anak menjadi kreatif, aktif dan menyenangkan. (6) Pembelajaran lebih efektif, karena terfokus pada media gambar. (7) Pembelajaran akan kondusif, karena perhatian siswa tertuju pada media gambar yang telah disediakan. (8) Guru mudah untuk mengevaluasi hasil kegiatan anak terutama pada aspek minat dan kemampuan siswa. (9) Dapat dijadikan tolak ukur pada pembelajaran berikutnya.
\end{abstract}

Kata Kunci : Kemampuan, Minat, dan Media Gambar

\section{PENDAHULUAN}

Proses pembelajaran yang bermutu tergantung pada guru yang mampu dan dapat mengaktifkan siswanya dalam proses belajar dimana siswa diberi kesempatan untuk mencoba, mengalami dan dapat melaksanakan atau mempraktekkan apa yang telah dipelajarinya untuk memperoleh hasil yang lebih baik. H.G. Tarigan mengemukakan bahwa keterampilan berbahasa memiliki empat komponen, yaitu : keterampilan menyimak, keterampilan berbicara, keterampilan membaca dan keterampilan menulis ( H.G. Tarigan : $1968: 1$ )

Keempat keterampilan berbahasa di atas merupakan suatu kesatuan yang tidak dapat dipisahkan, tetapi hanya dapat dibedakan. Keterampilan yang satu bergantung kepada ketiga keterampilan yang lainnya. Contohnya seseorang trampil menulis karena mampu membaca ,menyimak, dan berbicara. Untuk itu dapat disimpulkan bahwa pengajaran Bahasa Indonesia dalam aspek menulis merupakan salah satu komponen yang dapat menentukan dan mencapai tujuan pembelajaran yang diharapkan.

Kenyataan di lapangan, sebagian besar siswa masih kurang memiliki kemampuan dalam menuangkan ide-ide atau gagasan yang dapat dituliskan pada sebuah karangan. Salah satu alternatif untuk memecahkan masalah siswa tersebut adalah dengan dilakukannya kegiatan menulis karangan yang menggunakan media gambar. Melalui kegiatan ini siswa dilatih untuk mengekspresikan perasaan dan pikirannya sehingga dapat mengungkapkan ide-ide dan gagasan dalam bentuk menulis karangan. Di samping itu, siswa dilatih menulis karangan dengan ejaan yang benar sesuai dengan tema gambar. Secara bertahap siswa dapat berekspresi mulai dari penetapan paragraf pada gambar seri yang tepat kemudian dapat 
mengembangkan pokok pikiran melalui membuat kalimat sederhana sampai pada peulisan karangan teks eksemplum dalam bentuk fabel yang diharapkan.

Dari hasil prestasi rata-rata siswa dari sejumlah 26 siswa pada mata pelajaran Bahasa Indonesia di semester satu tahun pelajaran 2019/2020 hanya mencapai 59,00 sedangkan Kriteria Ketuntasam Minimal sebesar 76,00 dengan kata lain belum mencapai target yang diharapkan.

Berdasarkan hasil tersebut, untuk mengatasi kesulitan siswa dalam menulis karangan, penulis mengadakan perbaikan pembelajaran pada mata pelajaran Bahasa Indonesia dengan Penelitian Tindakan Kelas dengan judul Meningkatkan Minat dan Kemampuan Siswa Kelas VII.A SMP Negeri 2 Pujut Semester I Tahun Pelajaran 2019/2020 dalam Menulis Karangan Teks Eksemplum melalui Media Gambar.

\section{Rumusan Masalah}

Berkaitan dengan permasalahan tersebut di atas, maka dapat dirumuskan masalah sebagai berikut : Bagaimanakah meningkatkan minat dan kemampuan siswa kelas VII.A SMP Negeri 2 Pujut Semester I Tahun Pelajaran 2019/2020 dalam menulis karangan teks eksemplum melalui Media Gambar?

\section{Tujuan Penelitian}

Adapun tujuan yang diharapkan dalam penelitian ini adalah untuk Meningkatkan minat dan kemampuan siswa kelas VII.A SMP Negeri 2 Pujut Semester I Tahun Pelajaran 2019/2020 dalam menulis karangan Teks Eksemplum melalui Media Gambar.

\section{Manfaat Penelitian}

Melalui hasil Penelitian Tindakan Kelas ini diharapkan dapat memberikan manfaat:

1. Bagi Siswa :

a. Meningkatkan motivasi siswa dalam belajar menulis karangan teks eksemplum dalam bentuk fabel dengan menggunakan media gambar.

b. Mengembangkan kemampuan berfikir kreatif, kritis dan komunikatif dalam menulis sesuai dengan ejaan yang benar.
c. Siswa aktif dalam proses pembelajaran Bahasa Indonesia.

2. Bagi Guru :

a. Mengetahui media yang sesuai dalam proses belajar mengajar dan dapat mengembangkan penggunaan media gambar secara variatif.

b. Meningkatkan kwalitas pembelajaran bahasa Indonesia khususnya dalam menulis karanganteks eksemplum dalam bentuk fabel .

c. Memperbaiki proses pembelajaran Bahasa Indonesia.

3. Bagi Sekolah :

a. Termonivasi untuk menyediakan media gambar yang sesuai, sehingga dapat menumbuhkan minat siswa belajar.

b. Meningkatkan prestasi sekolah

c. Meningkatkan kompetensi lulusan dan kinerja guru pada pelajaran Bahasa Indonesia di sekolah.

4. Bagi Dinas :

a. Meningkatkan prestasi pendidikan VII SMP Negeri 2 Pujut Kabupaten Lombok Tengah.

b. Meningkatkan profesionalisme guruguru yang ada VII SMP Negeri 2 Pujut Kabupaten Lombok Tengah.

\section{LANDASAN TEORI DAN KAJIAN PUSTAKA \\ Pengertian Media}

Media berasal dari bahasa latin "medium" yang secara harfiah berarti "perantara" atau "pengantar" yaitu perantara atau pengantar sumber pesan dengan penerima pesan. Schramm (1977) mengemukakan bahwa media pembelajaran adalah teknologi pembawa pesan yang dapat dimanfaatkan untuk keperluan pembelajaran. Sementara Briggs (1977) berpendapat bahwa media pembelajaran adalah sarana fisik untuk menyampaikan isi/materi pembelajaran seperti : buku,film, video dsb.

Gambar adalah segala sesuatu yang diwujudkan secara visual ke dalam bentuk dua dimensi sebagai hasil perasaan dan pikiran. teori Piaget (Mohamad Surya : 2004 ) usia anak $6-12$ tahun perkembangan kecerdasannya pada peringkat operasional konkrit (concrete operational) anak telah dapat membuat pemikiran tentang situasi atau hal konkrit secara logis menyatakan bahwa anak usia sekolah dasar berada pada tahap 
operasional konkrit. Hal ini menunjukkan bahwa anak sangat menyukai benda yang nyata dan anak memiliki daya fantasi yang sangat tinggi.

\section{Tujuan Media}

Tujuan media pembelajaran adalah dapat menyalurkan suatu pesan, merangsang fikiran, perasaan, dan kemauan peserta didik sehingga dapat mendorong terciptanya proses belajar pada diri peserta didik dan mempermudah bagi guru dalam menyampaikan materi pembelajaran. Adapun jenis media belajar diantaranya : (1) Media visual , (2) Media audial , (3) Projected still dan (4) Projected motion

\section{Fungsi Media Gambar}

Fungsi utama media adalah sebagai alat bantu mengajar yang mampu memengaruhi keadaan, iklim kelas dan lingkungan belajar yang efektif. Media gambar tidak hanya berfungsi sebagai alat bantu pengajaran saja, tetapi fungsi-fungsi tertentu yang terkandung dalam gambar.

\section{Keuntungan dan Kelemahan Media Gambar}

Keuntungan dari media gambar diantaranya : (a) Dapat menerjemahkan ide /gagasan yang sifatnya abstrak menjadi lebih realistis, (b) Banyak tersedia dalam bukubuku ( termasuk buku teks), majalah, surat kabar, kalender, dsb, (c) Mudah menggunakannya dan tidak memerlukan peraturan lain, (d) Tidak mahal bahkan mungkin tanpa mengeluarkan biaya untuk pengadaannya, (e) Dapat digunakan pada setiap tahap pembelajaran dan semua mata pelajaran/disiplin ilmu.

Kelemahan dari Media Gambar ; (a) Terkadang ukuran gambar-gambar terlalu kecil jika digunakan pada suatu kelas yang memiliki banyak siswa, (b) Gambar fotografik merupakan media dua dimensi yang tidak bisa menimbulkan kesan gerak. (Yeyen Patoni : 2010 )

\section{Media Gambar Sebagai Alat Pembelajaran Menulis Karangan}

Gambar adalah segala sesuatu yang diwujudkan secara visual ke dalam bentuk dua dimensi sebagai hasil perasaan dan pikiran. Teori Piaget (Mohamad Surya, 2004) usia anak $6-12$ tahun perkembangan kecerdasannya pada peringkat operasional konkrit ( concrete operational) anak telah dapat membuat pemikiran tentang situasi atau hal konkrit secara logis menyatakan bahwa anak usia sekolah dasar berada pada tahap operasional konkret, ini menunjukkan bahwa anak sangat menyukai benda yang nyata. Disamping itu anak juga memiliki daya fantasi yang sangat tinggi.

\section{Menulis Karangan}

Pengertian Menulis

Menulis adalah identik dengan mengarang atau membuat tulisan berdasarkan pada ide atau gagasan. Menulis dalam arti yang sempit yaitu membuat angka atau huruf yang ditulis pada kertas atau media lain.

\section{Manfaat Menulis}

Kegiatan menulis yang dilakukan bagi seseorang penulis mempunyai manfaat sebagai berikut : (a) Agar tidak lupa terhadap apa yang telah diperolehnya, (b) Dapat mencatat renungan-renungan, (c) Dapat mencatat pikiran-pikiran yang terpenting, (d0 Dapat mencatat ide dan gagasan-gagasan.

\section{Tujuan Menulis}

Menurut Mansoer Pateda (Maliati,2005 : 35 ) bahwa seseorang menulis didorong oleh beberapa factor, yaitu keharusan, promosi, kemanusiaan, mengharapkan sesuatu, pengembangan ilmu, kesusastraan, mengadu domba dan pemberitahuan, sehingga dapat menumbuhkan keinginan yang diwarnai dengan tujuan.

\section{Faktor yang Mempengaruhi Keterampilan} Menulis.

Para ahli berpendapat bahwa faktor yang mendorong kemampuan menulis adalah (a) Kemampuan mendapatkan tema karangan yang akan dikembangkan menjadi isi karangan, (b) Kemampuan mengembangkan tema menjadi kerangka atau sistematik isi karangan, (c) Kemampuan mengembangkan kerangka menjadi suatu karangan yang lengkap, (d) Kemampuan bidang ketatabahasaan, (d) Kemampuan bidang gaya bahasa yang meliputi diksi, memilih kalimat efektif,sugestif, dan menarik, (e) Kemampuan dalam bidang arti kata, (f) Kemampuan dalam bidang kosakata, (g) Kemampuan dalam bidang ejaan dan fungtuasif. 


\section{Menulis Karangan}

Menulis karangan merupakan salah satu keterampilan berbahasa dalam aspek menulis. Karangan dalam bentuk tulisan sehingga pesan yang disampaikan dalam tulisan tersebut dapat dipahami oleh pembaca.

Menulis karangan dengan ejaan yang benar merupakan keterampilan berbahasa yang masih dianggap sulit bagi siswa. Ada beberapa langkah untuk memotivasi minat dan kemampuan siswa yaitu dengan media gambar seri, siswa akan terangsang untuk menemukan tema atau topik karangan tersebut. Sebagaimana diungkapkan oleh (Juanda : 1996). Langkah-langkah yang dilakukan oleh siswa agar tidak menemui kesulitan dalam mengarang cerita, antara lain : 1) mencari topic; 2)menentukan tujuan; 3) kepada siapa karangan itu ditujukan; dan 4) mewujudkan karangan di atas kertas.

\section{Minat}

Apa itu Minat? Secara umum, pengertian minat adalah perhatian yang mengandung unsur-unsur perasaan. Minat merupakan dorongan atau keinginan dalam diri seseorang pada objek tertentu. Misalnya minat terhadap pelajaran, olahraga, atau hobi.

\section{Kemampuan}

Menurut Mohammad Zain dalam Milman Yusdi (2010:10) mengartikan bahwa Kemampuan adalah kesanggupan, kecakapan, kakuatan kita berusaha dengan diri sendiri. Sedangkan Anggiat M.Sinaga dan Sri Hadiati (2001:34) mendefenisikan kemampuan sebagai suatu dasar seseorang yang dengan sendirinya berkaitan dengan pelaksanaan pekerjaan secara efektif atau sangat berhasil.

\section{METODE PENELITIAN}

\section{Metode Penelitian}

Metode yang digunakan dalam penelitian tindakan kelas ini adalah deskriptif analitik, yaitu studi yang digunakan untuk mengumpulkan data, mendeskripsikan, mengolah, menganalisa, menyimpulkan, dan menafsirkan data sehingga memperoleh gambaran yang sistematis tentang kemampuan mengarang jenis teks eksemplum dalam bentuk fabel.

\section{Subjek dan Seting Penelitian}

Tempat pelaksanaan penelitian di SMP Negeri 2 Pujut Kabupaten Lombok
Tengah. Subjek penelitian adalah peserta didik kelas VII.A SMP Negeri 2 Pujut, tahun pelajaran 2019/2020 yang terdiri dari 13 putra dan 13 putri.

\section{Instrumen Penelitian}

Untuk memperoleh data yang diperlukan oleh penulis, digunakan instrumen pengumpulan data sebagai berikut:

Tes Uji Kompetensi

Tes uji kompetensi digunakan untuk memperoleh data mengenai hasil belajar siswa yang dilaksanakan setelah pembelajaran berlangsung yaitu dengan menggunakan media gambar. Tes berupa pemberian tugas menulis karangan teks eksemplum dalam bentuk fabel sederhana.

Lembar Observasi

Lembar observasi disusun untuk memperoleh gambaran secara langsung tentang pelaksanaan pembelajaran menulis teks eksemplum dengan media gambar di kelas VII.A SMP Negeri 2 Pujut . Observasi tindakan dilakukan oleh guru lain yang bertindak sebagai observer . Lembar observasi disusun untuk mengamati peneliti dalam melaksanakan tindakan kelas, kondisi kelas, dan keaktifan siswa dalam proses pembelajaran.

\section{Prosedur Penelitian}

Penelitian tindakan kelas (PTK) ini dilaksanakan dengan empat tahapan sesuai dengan model John Elliot (Muslihuddin, 2010:72) yang dimulai dari perencanaan, pelaksanaan, pengamatan, dan refleksi. Adapun alur pelaksanaan tindakan dapat dilihat pada gambar 3.1 berikut.

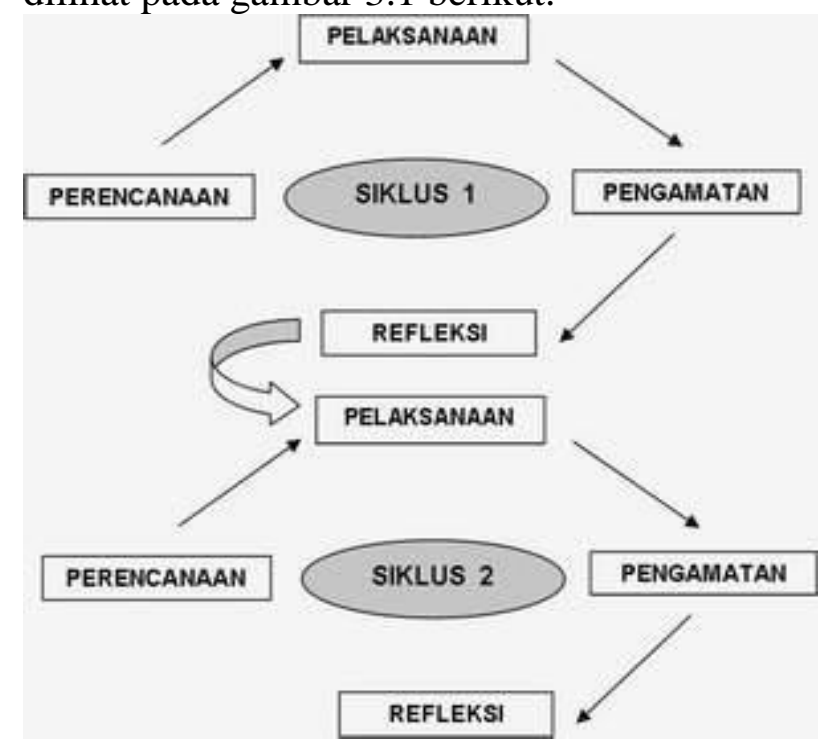




\section{Gambar ;Alur Pelaksanaan Tindakan dalam Penelitian Tindakan Kelas Berdasarkan Model John Elliot}

Secara garis besar tahapan-tahapan penelitian tindakan kelas dijabarkan sebagai berikut Perencanaan ( Planning ), Pelaksanaan Tindakan ( Action ), Pengamatan ( Observation ), Refleksi ( Reflection)

\section{Pengolahan Data}

Langkah-langkah pengolahan data dalam penelitian ini adalah sebagai berikut: (1) Mengolah data yang terkumpul , (2) Menyeleksi data , (3) Mengklasifikasikan dan menabulasikan data, (3) Menghitung persentase, (4) Menyimpulkan hasil penelitian setelah data dianalisis.

\section{Analisis Data}

Analisis data yang digunakan dalam penelitian ini yaitu teknik kuantitatif yang berupa perhitungan dan teknik kualitatif yang berupa uraian.

\section{HASIL PENELITIAN DAN \\ PEMBAHASAN \\ Hasil Penelitian \\ Kondisi Awal}

Pada bab ini akan menyajikan hasil analisis data yang telah diperoleh Sebelum melakukan tindakan dalam penelitian. Peneliti melakukan observasi awal di kelas tentang prestasi pelajaran bahasa Indonesia dalam menulis karangan. Hasil observasi menunjukkan bahwa hasil belajar siswa pada mata pelajaran bahasa Indonesia terutama dalam menulis karangan teks eksemplum dalam bentuk fabel masih tergolong rendah dan guru masih belum optimal memanfaatkan media pembelajaran. Berdasarkan hal tersebut maka diputuskanlah untuk menggunakan media gambar dalam materi menulis karangan jenis teks eksemplum dalam bentuk fabel pada siswa SMP Negeri 2 Pujut kabupaten Lombok Tengah tahun pelajaran 2019/2020.

Pembelajaran dimulai dengan mengadakan tugas awal di kelas VII.A untuk mengetahui kemampuan awal siswa dalam menulis karangan teks eksemplum dalam bentuk fabel. Nilai tugas awal dijadikan acuan untuk mengetahui hasil kemampuan siswa kelas VII.A setelah menggunakan media gambar. Tugas awal tentang menulis karangan sederhana teks eksemplum dalam bentuk fabel. Perolehan nilai tugas awal ini akan dijadikan acuan untuk mengetahui peningkatan hasil kemampuan siswa setelah menggunakan media gambar. Berikut disajikan data hasil belajar siswa pada prasiklus.

Tabel 4.1

\section{Data Hasil Belajar Siswa pada Prasiklus}

Berdasarkan hasil pengolahan data rata-rata hasil belajar siswa 69 dengan nilai tertinggi 80 dan nilai terendah 60 . Siswa yang hasil belajarnya di atas KKM hanya 10 orang atau hanya 38,46\% dari 26 siswa dengan nilai KKM yang ditetapkan yaitu 75 . Hal ini memberikan gambaran bahwa hasil kemampuan siswa pada mata pelajaran Bahasa Indonesia tentang menulis karangan teks eksemplum dalam bentuk fabel masih tergolong rendah.

\section{Tindakan Siklus I}

Untuk mengetahui hasil belajar siswa, maka pada akhir siklus I dilakukan penilaian hasil karangan sehingga diperoleh rata-rata nilai siswa 77,33 dengan nilai tertinggi 90 dan nilai terendah 60 . Siswa yang hasil belajarnya di atas KKM ada 15 orang atau 57,69\% dari 26 siswa dengan nilai KKM yang ditetapkan yaitu 75. Hal ini memberikan gambaran bahwa ada peningkatan hasil belajar siswa dari prasiklus ke siklus I.

\section{Refleksi}

Berdasarakan hasil belajar pada siklus 1 karena nilai siswa masih dibawah KKM yang ditetapkan maka dilanjutkan kesiklus II dengan perbaikan-perbaikan pada kegiatan pelaksanaan sehingga diperoleh hasil yang diharapakn.

\section{Tindakan Siklus II}

\section{Perencanaan}

\section{Pelaksanaan}

Berdasarkan hasil pengolahan nilai siswadiperoleh nilai rata-rata siswa 88,50 dengan nilai tertinggi 95 dan nilai terendah 80. Siswa yang hasil belajarnya diatas KKM ada 26 orang atau $100 \%$ dari nilai KKM yang ditetapkan yaitu 75. Hal ini memberikan gambaran bahwa ada peningkatan hasil belajar siswa dari siklus I ke siklus II, karena hasil belajar siswa telah mencapapi nilai 
$\mathrm{KKM} \geq 75$ dengan ketuntasan kelasikal $\geq 85$ maka penelitian dihentikan pada siklu II

\section{Pembahasan}

Dari hasil pembelajaran menggunakan alat peraga media gambar dan jawaban soalsoal evaluasi yang diberikan, kemudian penulis menggunakan jawaban-jawaban tersebut untuk mengetahui apakah pembelajaran Bahasa Indonesia menggunakan alat peraga media gambar tesebut dapat meningkatkan hasil belajar siswa kelas VII.A SMP Negeri 2 Pujut Kabupaten Lombok Tengah. Berikut ini adalah data yang diperoleh dari hasil pra siklus, siklus pertama dan siklus ke dua.

Tabel 4.1Rekapitulasi Nilai PraSiklus, Siklus Pertama dan Siklus Kedua

\begin{tabular}{|c|l|c|c|c|}
\hline No & Uraian & Prasiklus & $\begin{array}{c}\text { Siklus } \\
\text { I }\end{array}$ & $\begin{array}{c}\text { Siklus } \\
\text { II }\end{array}$ \\
\hline 1 & Rata-Rata & 69,33 & 77,33 & 88,50 \\
\hline 2 & $\begin{array}{l}\text { Nilai } \\
\text { Tertinggi }\end{array}$ & 70 & 80 & 95 \\
\hline 3 & $\begin{array}{l}\text { Nilai } \\
\text { Terendah }\end{array}$ & 50 & 60 & 70 \\
\hline 4 & $\begin{array}{l}\text { Persentase } \\
\text { Ketuntasan }\end{array}$ & 38,46 & 57,69 & 100 \\
\hline
\end{tabular}

Berdasarkan hasil penelitian selama dua siklus yang bertujuan untuk meningkatkan kemampuan siswa pada materi menulis karangan dengan menggunakan media gambar, terlihat pada pelaksanaan siklus pertama dan ke dua telah menunjukkan hal-hal sebagai berikut; (1) Proses pembelajaran bahasa Indonesia dengan menggunakan alat peraga media gambar, (2) Keefektifan Alat Peraga

\section{PENUTUP}

\section{Simpulan}

Berdasarkan hasil tindakan yang telah dilaksanakan dalam dua siklus dan indikatorindikator yang telah ditetapkan, maka dapat dikemukakan simpulan sebagai berikut (1) Media gambar dapat meningkatkan minat siswa dalam proses pembelajaran bahasa Indonesia khususnya menulis karangan teks eksemplum dalam bentuk fabel pada siswa kelas VII.A SMP Negeri 2 Pujut Kabupaten Lombok Tengah , (2) Media Gambar dapat meningkatkan kemampuan Siswa menulis karangan teks eksemplum dalam bentuk fabel mata pelajaran Bahasa Indonesia pada siswa kelas VII.A SMP Negeri 2 Pujut Kabupaten Lombok Tengah, Peningkatan minat dan kemapuan dapat dilihat pada nilai rata-rata siswa siklus $\mathrm{I}=77,33$ menjadi 88,50 pada siklus II

Saran

Berdasarkan hasil paparan dari hasil penelitian tindakan kelas yang telah dilaksanakan ada beberapa saran; (1) Agar guru kreatif dalam menyusun rencana pelaksanaan pembelajaran dan melaksanakan pembelajaran yang inovatif pada mata pelajaran bahasa Indonesia yaitu menggunakan metode dan media yang bervariasi dalam melaksanakan pembelajaran, (2) Kepala sekolah mendorong guru untuk mempraktikkan penggunaan media secara variatif .

\section{DAFTAR PURTAKA}

Azhar Arsyad. (2011). Media Pembelajaran. Jakarta: Raja Grafindo Persada.

Burhan Nurgiantoro. (2009). Penilaian dalam Pengajaran Bahasa dan Sastra.Yogyakarta: BPFE.

Dadan Djuanda. (2006). Pembelajaran Bahasa Indonesia yang Komunikatif dan Menyenangkan. Jakarta: Departemen Pendidikan Nasional.

H. Hamzah B. Uno \& Nina Lamatenggo. (2010). Teknologi komunikasi \& informasi pembelajaran. Jakarta: Bumi Aksara.

Hasan Alwi. (2005). Kamus Besar Bahasa Indonesia. Jakarta. Balai Pustaka

Henry Guntur Tarigan. (2008). Menulis sebagai Keterampilan Berbahasa. Bandung: Angkasa.

Maleong, L. J. (2000). Metodologi Penelitian Kualitatif. Bandung: PT Remaja Rosdakarya.

Muhammad Asrori (2008) Psikologi Pembelajaran. Bandung: Wacana Prima.

Muhibbin Syah. (2010). Psikologi Pendidikan. Bandung: Remaja Rosdakarya

Nana Sujana. (2005) Media Pengajaran. Bandung: Sinar Baru Algesindo

Semi, M. Atar. 2003. Menulis Efektif. Padang: Angkasa Raya 